\title{
An Analysis of the Impact of Customer Perception on Commercial Banks Positioning: A Study on Government Commercial Banks
}

\author{
Asifa Nargis ${ }^{1 *}$ Gourab Chakma ${ }^{1,2}$ Kamrul Hossain ${ }^{1,3}$ \\ 1.Lecturer, Department of Management, Rangamati Science and Technology University Rangamati, Rangamati- \\ 4500, Bangladesh \\ 2.Lecturer, Department of Management, Rangamati Science and Technology University Rangamati, Rangamati- \\ 4500, Bangladesh \\ 3.MBA (Marketing), Department Of Marketing, Comilla University,Kotbari, Comilla, Bangladesh
}

\begin{abstract}
The banking sector becoming a very much competitive sector in Bangladesh. Day by day this competition is increasing. At present, there are 6 government commercial banks, 43 private commercial banks, 9 foreign banks, and 3 state-owned specialized banks are operating in Bangladesh. This research study is mainly conducted to find out the impact of customer perception on government commercial banks' positioning. The researcher tried to find out what customers think, what customers want from the government commercial banks, what must be changed to retain existing customers and attracting new customers, what services must be added comparatively to the private commercial banks and providing some recommendations are the main objectives of this research study. Here the researcher conducts a research survey over 100 respondents who are customers of government commercial banks for collecting primary data. The researcher also collects secondary data from different websites, books, and journals, and research papers. SPSS has been used for analyzing collected data for descriptive statistics, correlation analysis, hypothesis testing, and other general analysis. From the research study, it has found that customers are not happy with employee's behavior, ATM services of government commercial banks, number of ATM booths. They want more promotional advertisements from government commercial banks, more professionalism from the employees of government commercial banks, more simplicity in account opening and loan getting procedure. The researcher has found that customers have faith and believe in government commercial banks but as most of the time they do not get quick services from the government commercial bank so negative positioning is creating in consumer minds that will not be good for government commercial banks in the long run for their positioning as well as for their profitability.
\end{abstract}

Keywords: perception, positioning. Government commercial banks, private commercial banks.

DOI: $10.7176 / \mathrm{JMCR} / 80-04$

Publication date:July $31^{\text {st }} 2021$

\subsection{Introduction}

The banking sector is one of the most interesting sectors in Bangladesh as well as for the whole world because the economy of the country fully dependent on the banking sector. In Bangladesh, there are two types of commercial banks. One is government commercial banks and another one is private commercial banks. Sonali bank ltd. Janta bank ltd, Rupali bank ltd, Agrani bank ltd are the most well-known Government commercial banks in Bangladesh. On the other hand Pubali bank ltd, Islami bank Bangladesh ltd, Standard Chartered bank Bangladesh ltd, Eastern bank ltd, Dutch bangla bank ltd, IFIC bank ltd are the most well-known private commercial banks in Bangladesh. Between these two types of banks, people mostly believe in Government commercial banks because they think doing transactions in government commercial banks is safe than the private commercial banks. But nowadays private commercial banks attracting customers towards them by providing extraordinary services. So a large number of customers are switching from government commercial banks to private commercial banks.

\subsection{Research objectives}

- To find out problems faced by customers of government commercial banks.

- To assess the needs and wants of government commercial banks customers.

- To find out the differences between government commercial banks services and private commercial banks services.

- To provide some recommendations for overcoming customers' problems.

\subsection{Rationale of the study}

Today's banking sector has become very much competitive in Bangladesh. 42 private commercial banks are operating within the country along with government commercial banks. Private commercial banks focus on some 
points to attract their customers that are ignored by the government commercial banks. Senior citizens of our country have faith in government commercial banks whether present generation prefers private commercial banks because they are mainly focusing on one-stop service and polite behavior as well as fast services that must be taken into consideration by the government commercial banks. To survive in this competitive marketplace every organization must be alert about themselves and competitors. To retain existing customers and attracting new customer's government commercial banks must try to provide better and unique services than the private commercial banks. If any commercial banks whether it is government or private commercial banks take time to make effective decisions about what to do and how to do then they will suffer in their business. So now it becomes an issue that what is customer perception regarding any particular bank and their services. It has to know that what customers are thinking must be added within the shortest possible time. It is also necessary to know competitors' actions so that they can take their decisions effectively. Without knowing customer's needs, wants, and demands as well as competitor's actions it becomes impossible to make any effective decisions.

\subsection{Research methodology}

For this research study, the researcher uses a sample size of 100 respondents. Here all the respondents are the customers of the government commercial banks and private commercial banks. For this research study, the researcher uses both primary and secondary data. For collecting primary data the researcher surveys 100 respondents who have a transaction in both government banks and private banks. For collecting secondary data the research use newspaper, article, publications, journal, books, websites, etc. for analyzing all the collected data the researcher use table, pie chart, SPSS tools, etc.

\subsection{Research Hypothesis}

H1: There is a positive relationship between employee behavior and positioning of govt. commercial banks.

$\mathrm{H} 2$ : There is a positive relationship between 24 hours services of ATM booths and positioning of govt. commercial banks.

H3: There is a positive relationship between the number of ATM booths and positioning of govt. commercial banks.

H4: There is a positive relationship between one-stop banking service and positioning of govt. commercial banks. H5: There is a positive relationship between providing more promotional advertisement and positioning of govt. commercial banks.

H6: There is a positive relationship between Formalities and rules in the case of account opening and getting loans and positioning of govt. commercial banks.

H7: There is a positive relationship between giving importance to customers and positioning of govt. commercial banks.

H8: There is a positive relationship between time-consuming services and positioning of govt. commercial banks. H9: There is a positive relationship between crowdedness and positioning of govt. commercial banks.

H10: There is a positive relationship between employee's professionalism and positioning of govt. commercial banks.

\subsection{Literature Review}

Consumer Perception - Consumer perception pertains to how individuals form opinions about companies and the products they offer through the purchase they make. It is the process through which consumers select, organize, and interpret information in order to provide themselves with a meaningful and coherent view of the product or service (Kotler, 1984). It also refers to how customers view a product based on their own conclusions. These conditions are derived from a number of factors, such as price and other attributes of the product.

Banking sector in Bangladesh is characterized as a highly competitive and highly regulated sector. With a good number of banks already in operation and a few more in the pipeline, the market is becoming increasingly competitive day by day. For this purpose they are concerned about getting knowledge about their client's perception on their activities. Therefore, each commercial bank needs to generate knowledge on consumer's perception on its day to day activities (Jafirullah and Afzal, 2012)

A primary purpose of marketing strategy is the development of a competitive advantage strategy (Devlin and Ennew, 1997) that can provide customers with superior value compared to competitive offerings. According to an article by Ta and Har (2000), an essential first step is to ensure that bank's services correspond with client's short and long term needs. The essential task is the matching of the needs of bank consumers and the products and services of banks in order to develop a positioning strategy (Ta and Har, 2000).

Banks are struggling to find new ways to compete. As banks have begun to realize that no one can offer all products and all services and maintain the top position at the same time and be recognized a leading bank for all customers, the need to develop mission, organizational strengths and prepare answers concerning the strategic positioning has become equally challenging (Zineldin, 1996). 
Organizations nowadays know that they will not achieve perfect positioning through the traditional 4Ps approach of product marketing (Knox, 2004). Every bank has to consider how to enter a market and then how to build and protect its customer segment (Zineldin, 2002). Evaluation of the relationship between quality and positioning requires an understanding and examination of all of the elements of quality relative to the operations strategy (Zineldin, 1995, 1996, 2000).

\subsection{Analysis}

2.1.1. Gender of the respondents

Selected gender distribution is given below:

\section{Gender Distribution}

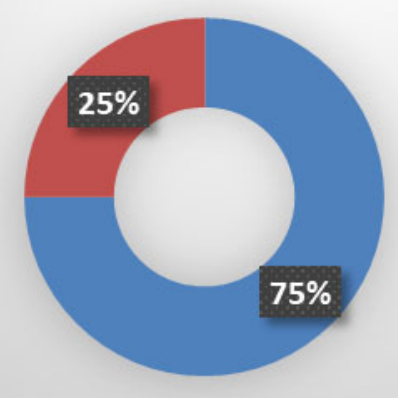

- Male

- Female

Figure 1: Gender distribution of the respondents.

Source: Field survey, 2021

This pie chart shows that the selected gender distribution for this research paper is $75 \%$ male respondents and $25 \%$ female respondents. Determine the percentage of respondents regarding their gender is an important part of any research work. Collected data might be different because of human ecology.

2.1.2 Age differentiation of the respondents

The selected age distribution is given below:

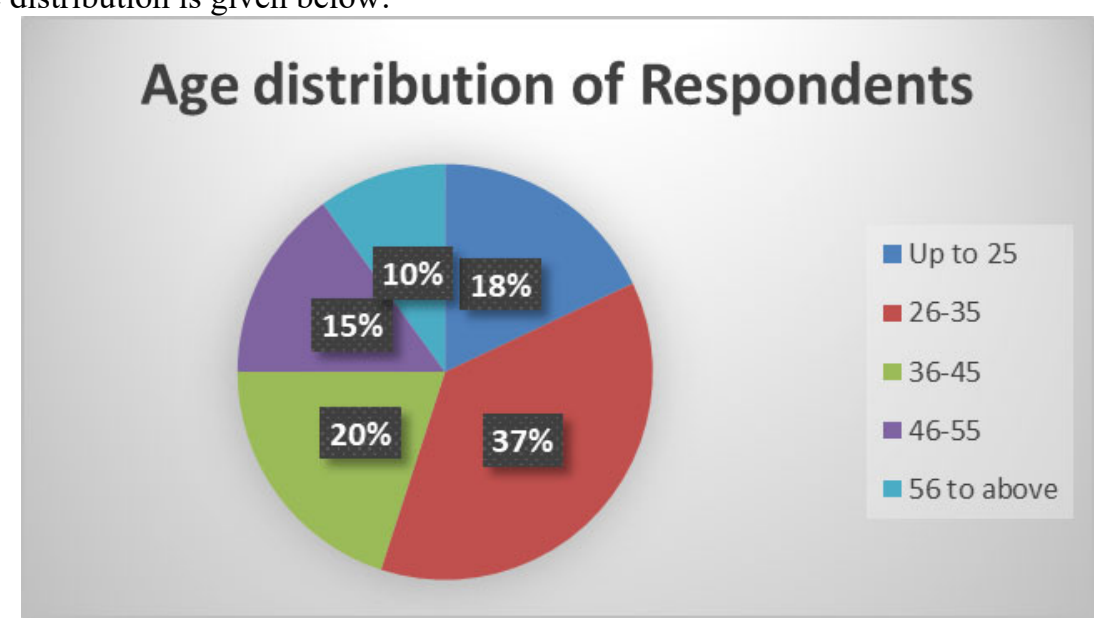

Figure 2: Age distribution of the respondents.

Source: Field survey, 2021

The most rational and quality data can be collected if the researcher can select the right aged respondents appropriately. Age dictates how much experience a respondent has regarding any particular topic. In this chart, the researcher has shown that most of the respondents were from the age range of 26-35 and the percentage is $37 \%$. On the other hand, $20 \%$ of respondents were from the age range of $36-45,18 \%$ of respondents were below $25,15 \%$ of respondents were between $46-55$, and the rest $5 \%$ were above 56 .

\subsubsection{Educational status of the respondents.}

The distribution of the educational status of the respondents is given below: 


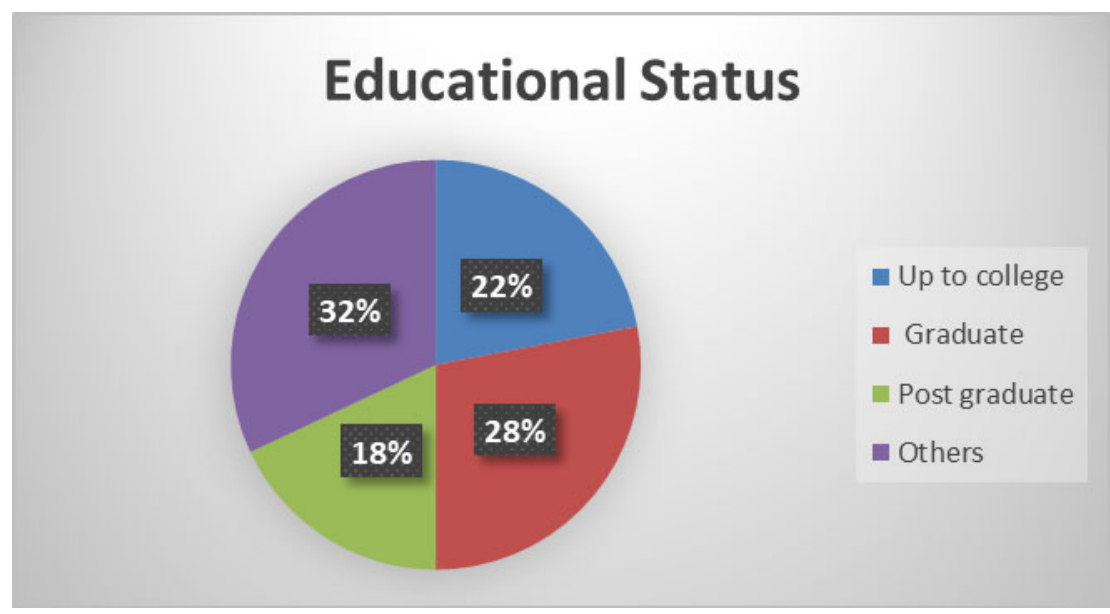

Figure 3: Educational status of the respondents.

Source: Field survey, 2021

As the researcher mentioned it before that the quality and persistence of the data depends on the knowledge of the respondents on that particular topic so from this point of view the educational status of the respondents was one of the most crucial concentrations of the researcher for this research paper. From this above pie chart, it can be seen that in this research $22 \%$ of respondents were studied up to college level, $28 \%$ respondents were graduate, $18 \%$ respondents were postgraduate, and the rest does not have an educational status yet.

\subsubsection{Marital status of the respondents}

Selected marital status is given below:

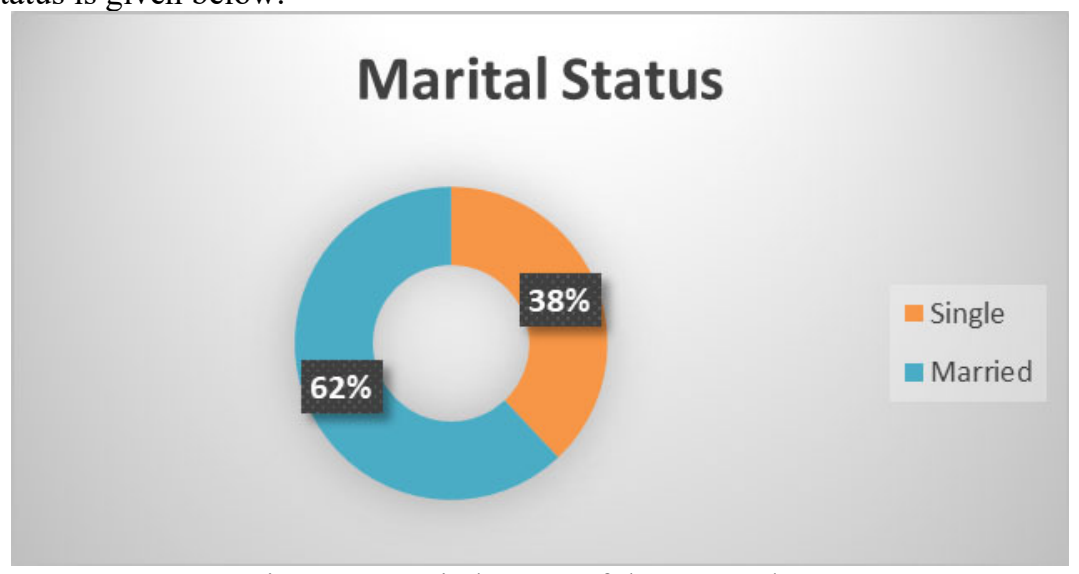

Figure 4: Marital status of the respondents

Source: Field survey, 2021

This pie chart shows that $38 \%$ of respondents are single and the rest $62 \%$ of respondents were married.

\subsubsection{Employee behavior is satisfactory in government commercial banks.}

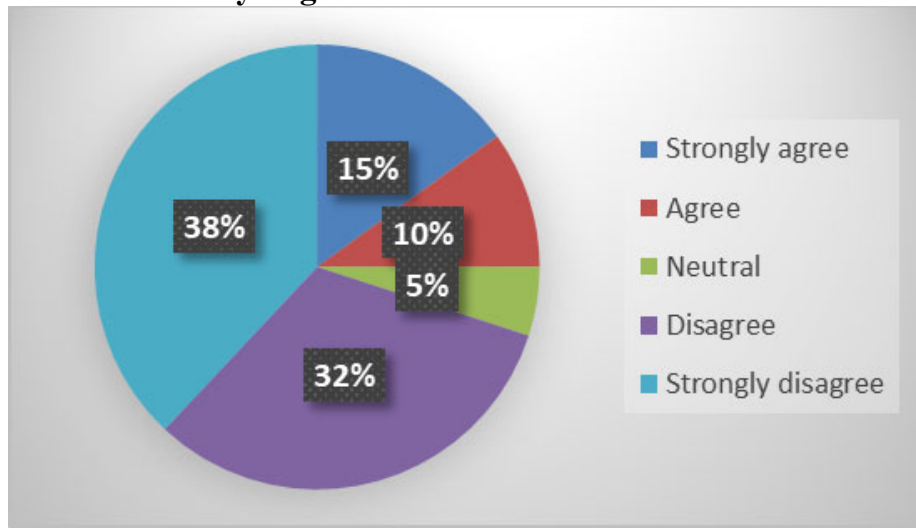

Figure 5: Employee behavior is satisfactory in government commercial banks.

Source: Field survey, 2021

From the above survey we found that $38 \%$ of respondents strongly disagree, $32 \%$ of respondents normally disagree with that statement. Although $10 \%$ of respondents agree and $15 \%$ of respondents strongly agree with 
the statement that employee behavior is satisfactory but almost $80 \%$ of respondents said that they are not satisfied with the behavior of government bank employees.

2.1.6 ATM booths are available 24/7 at government commercial banks.

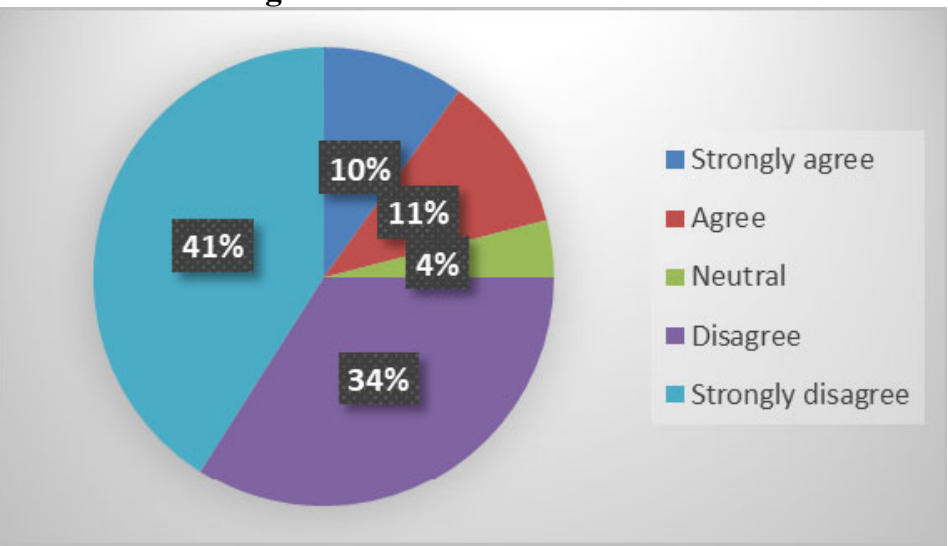

Figure 6: ATM booths are available 24/7 at government commercial banks

Source: Field survey, 2021

Here we can say that only $10 \%$ of respondents strongly agree and $11 \%$ of respondents normally agree that ATM booths of government commercial banks are available in 24 hours in 7 days. But 34\% of respondents disagree and $41 \%$ of respondents strongly disagree with that statement. That means that they do not get $24 / 7$ services from the government banks' ATM services.

\subsubsection{Government commercial banks numbers of ATM booths are available.}

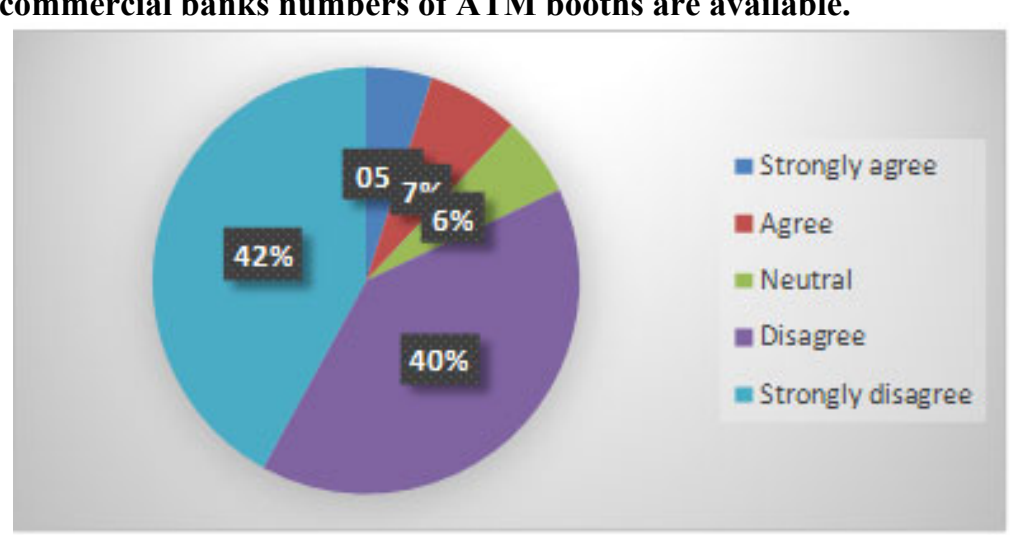

Figure 7 : Government commercial banks numbers of ATM booths are available.

Source: Field survey, 2021

From this research paper, it can be easily said that only a few respondents strongly agree and agree with the statement that ATM booths of government commercial banks are available. Most of the respondents are agree with that. $40 \%$ of respondents disagree and $42 \%$ respondents strongly disagree with that statement. That means more than $80 \%$ of respondents believe that numbers of ATM booths are not available.

2.1.8 Government commercial banks provided one-stop banking services.

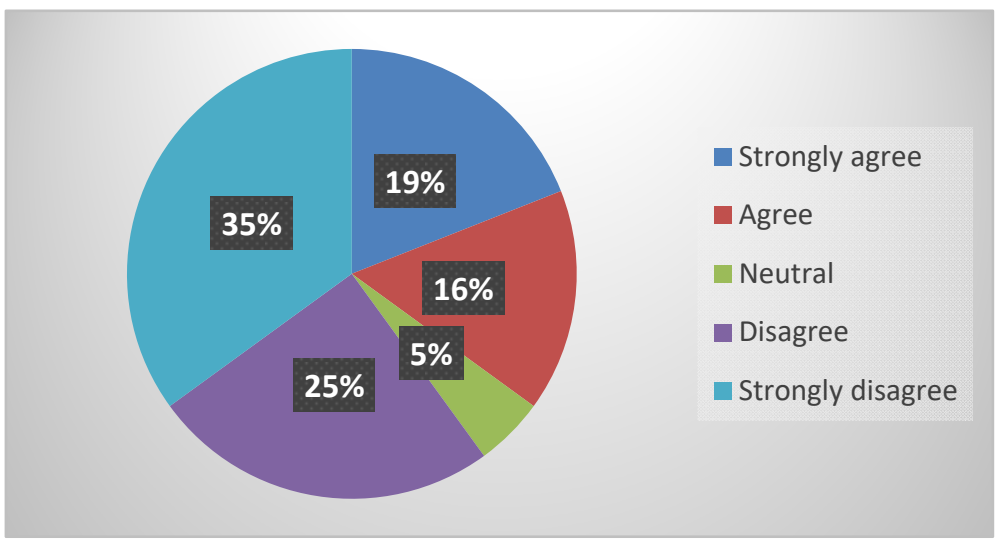

Figure 8: Government commercial banks provided one-stop banking services.

Source: Field survey, 2021 
From the survey, we can say that $19 \%$ of respondents strongly agree and $16 \%$ of respondents agree that they get one-stop service from government commercial banks. On the other hand, $25 \%$ of respondents disagree and $35 \%$ respondents strongly disagree that government commercial banks provide one-stop services.

\subsubsection{More promotional advertisements are needed by the government commercial banks.}

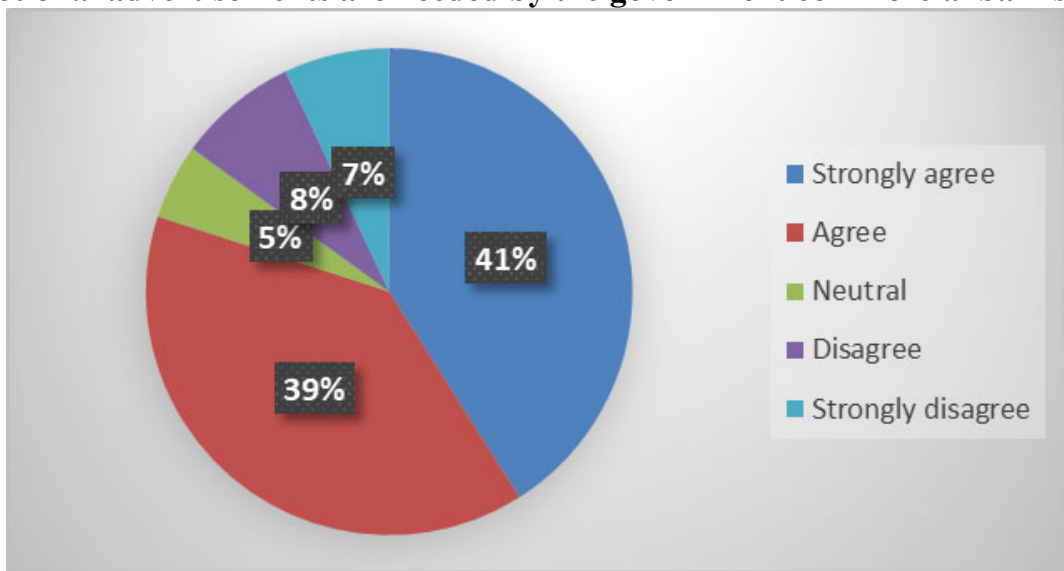

Figure 9 : More promotional advertisements are needed by the government commercial banks.

Source: Field survey, 2021

From the research study, it can be easily said that $41 \%$ of respondents strongly agree and $39 \%$ of respondents agree that more promotional advertisements are needed by the government commercial bank. Here $5 \%$ of respondents are neutral on that statement and rest of the respondents does not agree with that statement.

2.1.10 More formalities and rules have to be followed for services such as account opening and getting loans.

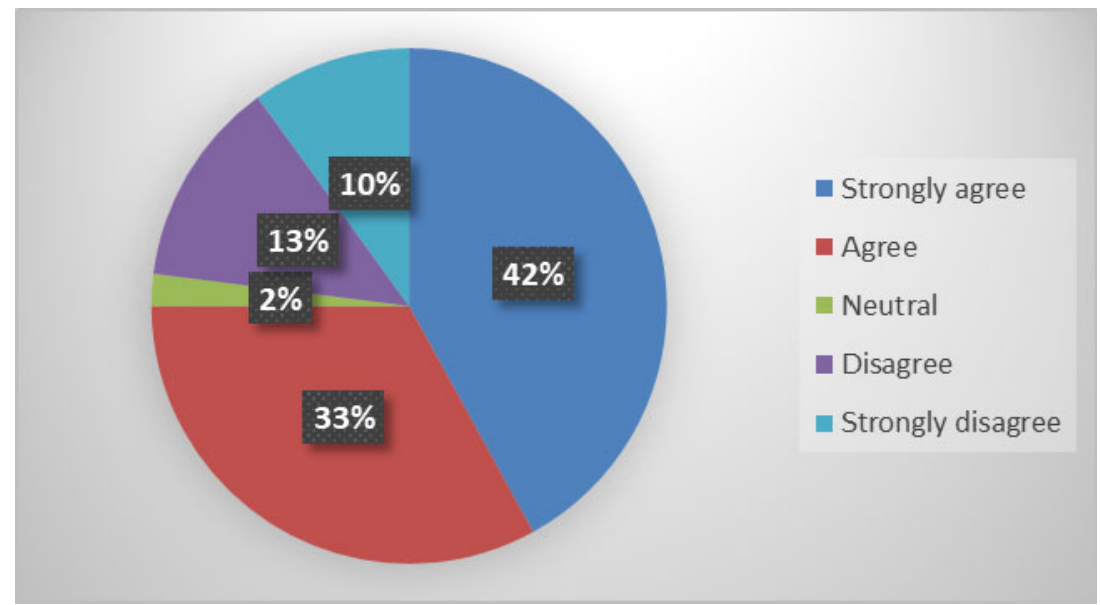

Figure 10: More formalities and rules have to be followed for services such as account opening and getting loans.

Source: Field survey, 2021

Most of the respondents believe that they have to follow more formalities and rules regulation while they go for account opening or getting any loans. From the survey it has found that $42 \%$ of respondents strongly agree, $33 \%$ of respondents are agree and only $2 \%$ of respondents are neutral here. On the other hand, $13 \%$ of respondents disagree and $10 \%$ of respondents strongly disagree with that. 


\subsubsection{Employees of government commercial banks do not give importance to their customers.}

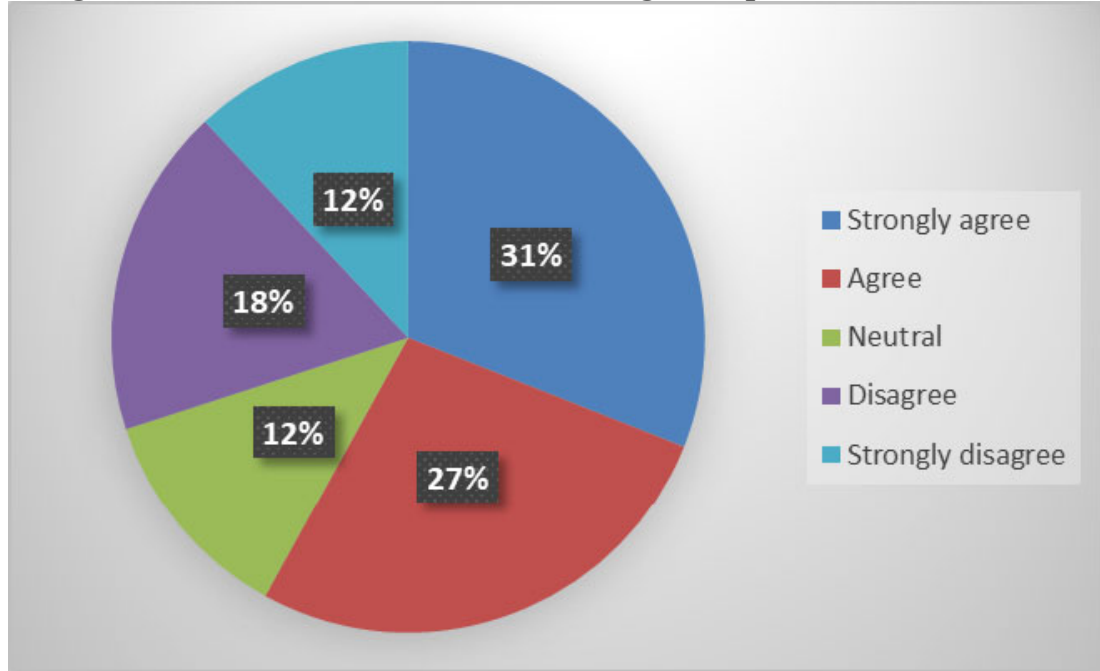

Figure 11: Employees of government commercial banks do not give importance to their customers.

Source: Field survey, 2021

From the survey over the respected customer of government commercial bank, it has found that most of the customer of these banks feels that employees of these banks do not give importance to their customers. $31 \%$ of respondents strongly agree and $27 \%$ of respondents agree that they do not get importance from the government bank employees as they expected. $12 \%$ of respondents are neutral on that statement. Almost $30 \%$ of respondents believe that they get importance from the employees of the government commercial banks.

\subsubsection{Getting services from government commercial banks is very much time-consuming.}

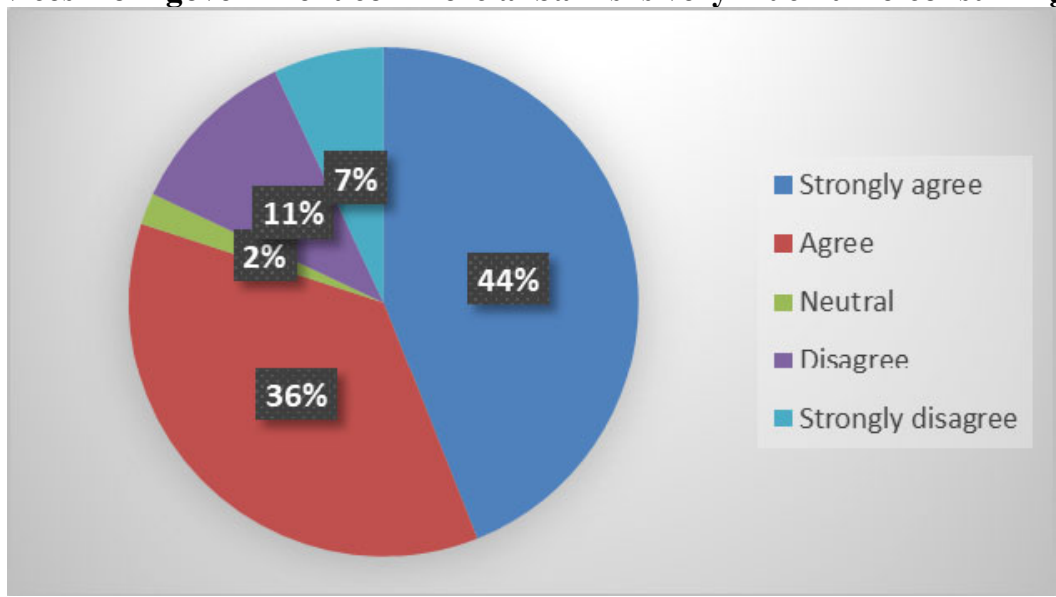

Figure 12: Getting services from government commercial banks is very much time-consuming.

Source: Field survey, 2021

From the survey, it can be easily said that $44 \%$ of respondents strongly agree and $36 \%$ of respondents agree that getting services from commercials banks is very time-consuming. Here only $2 \%$ of respondents are neutral. On the other hand, around $20 \%$ of respondents assume that getting services from government banks is not so much time-consuming. 


\subsubsection{Government commercial banks are very much crowded.}

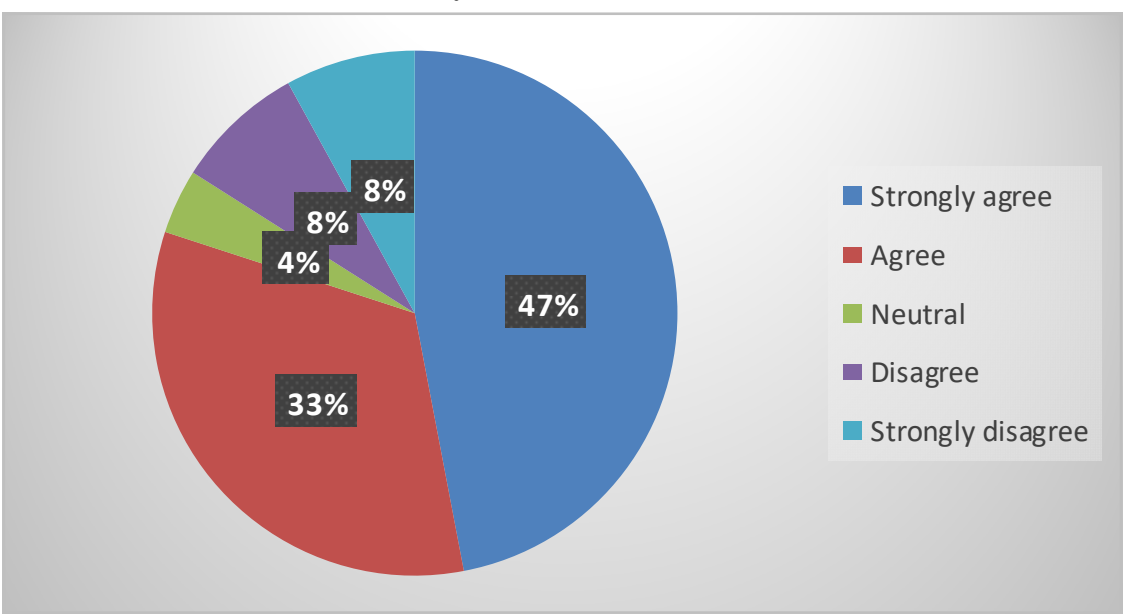

Figure 13: Government commercial banks are very much crowded.

Source: Field survey, 2021

From the survey, it has found that $47 \%$ of respondents strongly agree and $33 \%$ of respondents agree that government banks are very much crowded. $4 \%$ of respondents are neutral. $8 \%$ of respondents disagree and the rest of the $8 \%$ strongly disagrees with that statement.

\subsubsection{Employees are very professionals in government commercial banks.}

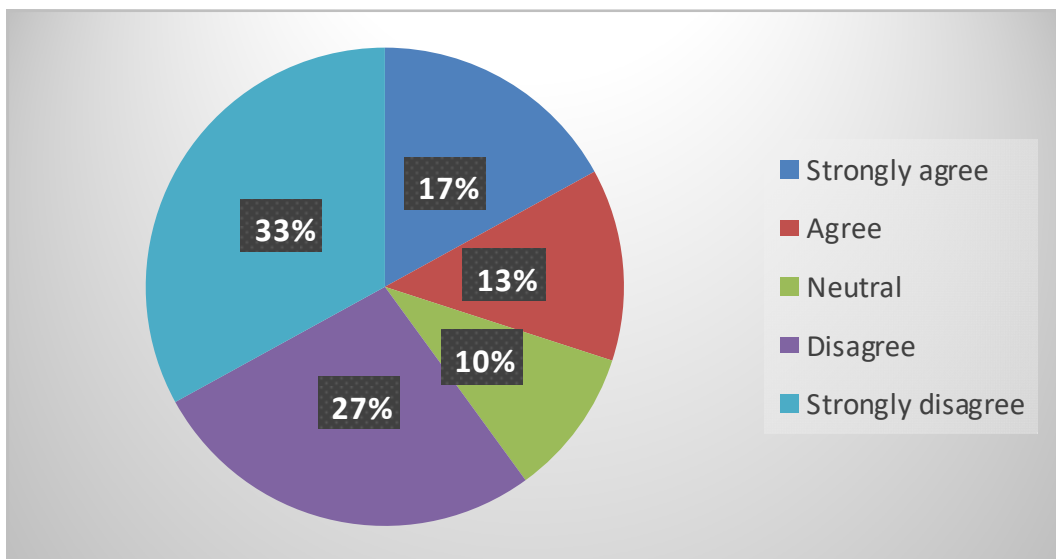

Figure 14: Employees are very professionals in government commercial banks.

Source: Field survey, 2021

From the survey, we can say that $17 \%$ of respondents strongly agree and $13 \%$ of respondents agree that employees of government banks are professionals. 10\% of respondents remain neutral. But on the contrary, almost $60 \%$ of respondents agree that employees are not so professionals in government commercial banks.

\subsubsection{Government commercial banks have a positioning in the consumer mind}

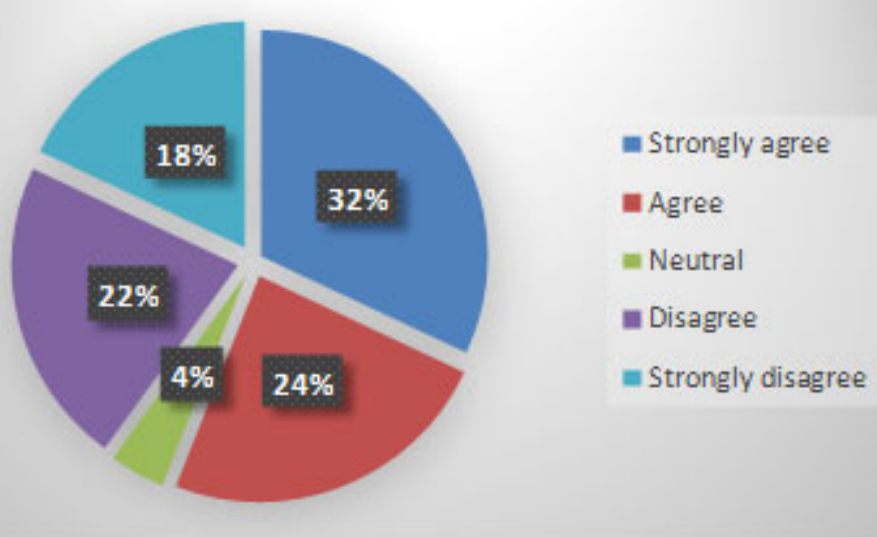

Figure 15: Government commercial banks have a positioning in the consumer mind.

Source: Field survey, 2021 
From the research study, the researcher has found that $32 \%$ of respondents strongly agree that government commercial banks have a positioning in customer mind. $24 \%$ of respondents agree and $4 \%$ of respondents are neutral. On the other hand, $22 \%$ of respondents disagree and $18 \%$ of respondents strongly disagree with the statement that government commercial banks have positioned in the consumer mind.

\section{Correlation analysis}

\begin{tabular}{|c|c|c|c|c|c|c|c|c|c|c|c|c|}
\hline & & $\begin{array}{l}\text { ployees_B } \\
\text { ehavior }\end{array}$ & \begin{tabular}{|c|} 
ATM \\
service \\
\end{tabular} & \begin{tabular}{|c|} 
NUMBER_of \\
ATM_booths \\
\end{tabular} & $\begin{array}{c}\text { One_stop_bankin } \\
\text { g_service } \text { _sere }\end{array}$ & $\begin{array}{c}\text { Promtional_Adve } \\
\text { rtisement }\end{array}$ & $\begin{array}{c}\begin{array}{c}\text { Formalities_a } \\
\text { nd_rules }\end{array} \\
\end{array}$ & $\begin{array}{c}\text { Customers_im } \\
\text { portance }\end{array}$ & $\begin{array}{c}\text { Time_cons } \\
\text { uming } \\
\end{array}$ & $\begin{array}{c}\text { Crow } \\
\text { ded }\end{array}$ & $\begin{array}{l}\text { ofession } \\
\text { balism }\end{array}$ & $\begin{array}{l}\text { nking_po } \\
\text { tioning }\end{array}$ \\
\hline $\begin{array}{l}\text { iployees_B } \\
\text { ivior }\end{array}$ & $\begin{array}{l}\text { Pearson } \\
\text { Correlation } \\
\begin{array}{l}\text { Sig. } \\
\text { tailed) }\end{array} \\
\mathrm{N}\end{array}$ & 100 & $\begin{array}{c}.966^{* *} \\
.000 \\
100\end{array}$ & $\begin{array}{r}.899^{* *} \\
.000 \\
100\end{array}$ & $\begin{array}{c}.936^{* *} \\
.000 \\
100\end{array}$ & $\begin{array}{c}.656^{* *} \\
.000 \\
100\end{array}$ & $\begin{array}{c}.684^{* *} \\
.000 \\
100\end{array}$ & $\begin{array}{r}.830^{* *} \\
.000 \\
100\end{array}$ & $\begin{array}{r}.647^{* *} \\
.000 \\
100\end{array}$ & $\begin{array}{c}.630^{* *} \\
.000 \\
100\end{array}$ & $\begin{array}{c}.960^{* *} \\
.000 \\
\\
100\end{array}$ & \\
\hline ATM service & 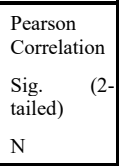 & $\begin{array}{c}.966^{* *} \\
.000 \\
100 \\
\end{array}$ & 100 & $\begin{array}{r}.939^{m+1} \\
.000 \\
100 \\
\end{array}$ & $\begin{array}{c}.903^{* *} \\
.000 \\
100 \\
\end{array}$ & $\begin{array}{c}.622^{* *} \\
.000 \\
100 \\
\end{array}$ & $\begin{array}{c}.648^{* *} \\
.000 \\
100 \\
\end{array}$ & $\begin{array}{c}.792^{* *} \\
.000 \\
100 \\
\end{array}$ & $\begin{array}{r}.615^{* *} \\
.000 \\
100 \\
\end{array}$ & $\begin{array}{c}.602^{* *+} \\
.000 \\
100 \\
\end{array}$ & $\begin{array}{l}.920^{* *} \\
.000 \\
\\
100 \\
\end{array}$ & \\
\hline $\begin{array}{l}\text { NUMBER_of } \\
\text { ATM_booths }\end{array}$ & 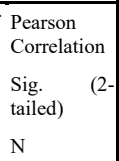 & $\begin{array}{c}.899^{* *} \\
.000 \\
100\end{array}$ & $\begin{array}{c}.939^{* *} \\
.000 \\
100\end{array}$ & 100 & $\begin{array}{c}.847^{* *} \\
.000 \\
100\end{array}$ & $\begin{array}{r}.590^{* * *} \\
.000 \\
100\end{array}$ & $\begin{array}{c}.620^{* *} \\
.000 \\
100\end{array}$ & \begin{tabular}{r|}
$.752^{* *}$ \\
.000 \\
100
\end{tabular} & $\begin{array}{r}.589^{* *} \\
.000 \\
100\end{array}$ & $\begin{array}{c}.580^{* *} \\
.000 \\
100\end{array}$ & $\begin{array}{l}.867^{* *} \\
.000 \\
100\end{array}$ & \\
\hline $\begin{array}{l}\text { One_stop_ba } \\
\text { nking_service }\end{array}$ & $\begin{array}{ll}\text { Pearson } \\
\text { Correlation } \\
\begin{array}{l}\text { Sig. } \\
\text { tailed) }\end{array} \\
\mathrm{N}\end{array}$ & $\begin{array}{c}.936^{* *} \\
.000 \\
100\end{array}$ & $\begin{array}{c}.903^{* *} \\
.000 \\
100\end{array}$ & $\begin{array}{r}.847^{* *} \\
.000 \\
100\end{array}$ & 100 & $\begin{array}{c}.742^{* *} \\
.000 \\
100\end{array}$ & $\begin{array}{c}.771^{* *} \\
.000 \\
100\end{array}$ & $\begin{array}{r}.875^{* *} \\
.000 \\
100\end{array}$ & $\begin{array}{r}.728^{* * *} \\
.000 \\
100\end{array}$ & $\begin{array}{c}.706^{* *} \\
.000 \\
100\end{array}$ & $\begin{array}{r}.982^{* *} \\
.000 \\
100\end{array}$ & 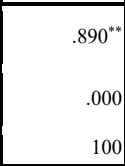 \\
\hline $\begin{array}{l}\text { Promtional_A } \\
\text { dvertisement }\end{array}$ & 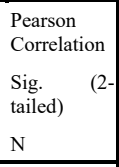 & $\begin{array}{c}.656^{* *} \\
.000 \\
100 \\
\end{array}$ & $\begin{array}{r}.622^{* *} \\
.000 \\
100 \\
\end{array}$ & $\begin{array}{r}.590^{* *} \\
.000 \\
100 \\
\end{array}$ & $\begin{array}{c}.742^{* *} \\
.000 \\
100 \\
\end{array}$ & 100 & $\begin{array}{c}.944^{* *} \\
.000 \\
100 \\
\end{array}$ & $\begin{array}{r}.878^{* *} \\
.000 \\
100 \\
\end{array}$ & $\begin{array}{r}.980^{* *} \\
.000 \\
100 \\
\end{array}$ & $\begin{array}{r}.975^{* *} \\
.000 \\
100 \\
\end{array}$ & $\begin{array}{c}.737^{* *} \\
.000 \\
100 \\
\end{array}$ & \\
\hline $\begin{array}{l}\begin{array}{l}\text { Formalities_a } \\
\text { nd_rules }\end{array} \\
\end{array}$ & $\begin{array}{ll}\text { Pearson } \\
\text { Correlation } \\
\begin{array}{l}\text { Sig. } \\
\text { tailed) }\end{array} \\
\mathrm{N}\end{array}$ & $\begin{array}{c}.684^{* *} \\
.000 \\
100\end{array}$ & $\begin{array}{c}.648^{* *} \\
.000 \\
100\end{array}$ & $\begin{array}{r}.620^{* *} \\
.000 \\
100\end{array}$ & $\begin{array}{c}.771^{* *} \\
.000 \\
100\end{array}$ & $\begin{array}{c}.944^{* *} \\
.000 \\
100\end{array}$ & 100 & $\begin{array}{r}.911^{* *} \\
.000 \\
100\end{array}$ & $\begin{array}{r}.948^{* *} \\
.000 \\
100\end{array}$ & $\begin{array}{c}.940^{* *+} \\
.000 \\
100\end{array}$ & $\begin{array}{c}.769^{* *} \\
.000 \\
\\
100\end{array}$ & 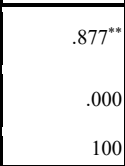 \\
\hline $\begin{array}{l}\begin{array}{l}\text { Customers_i } \\
\text { mportance }\end{array} \\
\end{array}$ & $\begin{array}{ll}\text { Pearson } \\
\text { Correlation } \\
\begin{array}{l}\text { Sig. } \\
\text { tailed) }\end{array} \\
\mathrm{N} \\
\end{array}$ & $\begin{array}{c}.830^{* *} \\
.000 \\
100 \\
\end{array}$ & $\begin{array}{c}.792^{* *} \\
.000 \\
100 \\
\end{array}$ & $\begin{array}{r}.752^{* *} \\
.000 \\
100\end{array}$ & $\begin{array}{c}.875^{* *} \\
.000 \\
100\end{array}$ & $\begin{array}{c}.878^{* *} \\
.000 \\
100\end{array}$ & $\begin{array}{c}.911^{* *} \\
.000 \\
100\end{array}$ & 100 & $\begin{array}{r}.877^{* *} \\
.000 \\
100 \\
\end{array}$ & $\begin{array}{c}.878^{* *} \\
.000 \\
100 \\
\end{array}$ & $\begin{array}{c}.879^{* *} \\
.000 \\
100\end{array}$ & \\
\hline $\begin{array}{l}\text { Time_consu } \\
\text { ming }\end{array}$ & 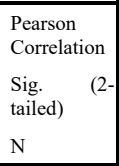 & $\begin{array}{c}.647^{* *} \\
.000 \\
100 \\
\end{array}$ & $\begin{array}{c}.615^{* *} \\
.000 \\
100 \\
\end{array}$ & \begin{tabular}{r|}
$.589^{* *}$ \\
.000 \\
100
\end{tabular} & $\begin{array}{r}.728^{* *} \\
.000 \\
100 \\
\end{array}$ & $\begin{array}{c}.980^{* *} \\
.000 \\
100 \\
\end{array}$ & $\begin{array}{c}.948^{* *} \\
.000 \\
100 \\
\end{array}$ & $\begin{array}{r}.877^{* *} \\
.000 \\
100 \\
\end{array}$ & 100 & $\begin{array}{c}.981^{* *} \\
.000 \\
100 \\
\end{array}$ & $\begin{array}{c}.724^{* *} \\
.000 \\
100 \\
\end{array}$ & \\
\hline Crowded & 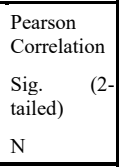 & $\begin{array}{r}.630^{* * *} \\
.000 \\
100 \\
\end{array}$ & $\begin{array}{c}.602^{* *} \\
.000 \\
100 \\
\end{array}$ & $\begin{array}{r}.580^{* *} \\
.000 \\
100 \\
\end{array}$ & $\begin{array}{c}.706^{* *} \\
.000 \\
100 \\
\end{array}$ & $\begin{array}{c}.975^{* * *} \\
.000 \\
100 \\
\end{array}$ & $\begin{array}{c}.940^{* *} \\
.000 \\
100 \\
\end{array}$ & $\begin{array}{r}.878^{* *} \\
.000 \\
100 \\
\end{array}$ & $\begin{array}{r}.981^{* *} \\
.000 \\
100 \\
\end{array}$ & 100 & $\begin{array}{r}.703^{* *} \\
.000 \\
100 \\
\end{array}$ & \\
\hline $\begin{array}{l}\text { Professionbal } \\
\text { ism }\end{array}$ & $\begin{array}{l}\begin{array}{l}\text { Pearson } \\
\text { Correlation } \\
\begin{array}{l}\text { Sig. } \\
\text { tailed) }\end{array} \\
\mathrm{N}\end{array} \\
\end{array}$ & $\begin{array}{r}.960^{* *} \\
.000 \\
100\end{array}$ & $\begin{array}{c}.920^{* *} \\
.000 \\
100\end{array}$ & $\begin{array}{r}.867^{* *} \\
.000 \\
100\end{array}$ & $\begin{array}{r}.982^{* *} \\
.000 \\
100\end{array}$ & $\begin{array}{c}.737^{* *} \\
.000 \\
100\end{array}$ & $\begin{array}{c}.769^{* *} \\
.000 \\
100\end{array}$ & $\begin{array}{r}.879^{* *} \\
.000 \\
100\end{array}$ & $\begin{array}{r}.724^{* *} \\
.000 \\
100\end{array}$ & $\begin{array}{c}.703^{*+*} \\
.000 \\
100\end{array}$ & 100 & .88 \\
\hline $\begin{array}{l}\text { Banking_posi } \\
\text { tioning }\end{array}$ & 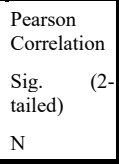 & $\begin{array}{r}.840^{* *} \\
.000 \\
100\end{array}$ & $\begin{array}{c}.809^{* *} \\
.000 \\
100\end{array}$ & $\begin{array}{c}.770^{m+1} \\
.000 \\
100\end{array}$ & $\begin{array}{c}.890^{* * *} \\
.000 \\
100\end{array}$ & $\begin{array}{c}.850^{* *} \\
.000 \\
100\end{array}$ & $\begin{array}{r}.877^{* *} \\
.000 \\
100\end{array}$ & $\begin{array}{l}.000 \\
100\end{array}$ & \begin{tabular}{r|}
$.863^{* *}$ \\
.000 \\
100
\end{tabular} & $\begin{array}{c}.856^{* *} \\
.000 \\
100\end{array}$ & $\begin{array}{c}.882^{* *} \\
.000 \\
100\end{array}$ & \\
\hline
\end{tabular}

evel (2-

Source: Field survey, 2021

On correlation analysis, we try to find out the relationship among various variables. Pearson correlation is used to finding the degree of relationship between several variables. Generally, two variables are correlated when they tend to simultaneously vary in the same direction. If both dependent and independent variables increase or decrease together, the correlation is said to be positive. But when one variable tends to increase and 
the other variables decrease the correlations are said to be negative. The results are shown in the above table. Employee behavior, ATM service, number of ATM booths, one-stop baking service, promotional advertisement, formalities and rules, customers importance, time-consuming, crowded, and professionalism have positive and significant correlation with the banks positioning at $1 \%$ level of significance. For example, the correlation between bank positioning and employee behavior was $0.840(\mathrm{p}=0.000)$ which supports hypothesis 1 , banks positioning and ATM service was $0.809(\mathrm{p}=0.000)$ which supports hypothesis 2 . The correlation between banks positioning and the number of ATM booths was $0.770(\mathrm{p}=0.000)$ which support hypothesis 3 , the correlation between bank positioning and one-stop banking service was $0.890(\mathrm{p}=0.000)$ which support hypotheses 4 , the correlation between banks positioning and promotional advertisements was $0.850(p=0.000)$ which supports hypotheses 5 , the correlation between bank positioning and formalities and rules was $0.877(p=0.000)$ which supports hypothesis 6 , the correlation between bank positioning and customer importance was $0.967(\mathrm{p}=0.000)$ which supports hypothesis 7 , the correlation between bank positioning and time consuming was $0.863(\mathrm{p}=0.000)$ which supports hypothesis 8 , the correlation between banks positioning and crowded was $0.856(p=0.000)$ which support hypothesis 9 , the correlation between bank positioning and professionalism was $0.882(\mathrm{p}=0.000)$ which supports hypothesis 10 .

\begin{tabular}{|l|c|c|c|c|}
\hline Model & $\mathrm{R}$ & R Square & $\begin{array}{c}\text { Adjusted R } \\
\text { Square }\end{array}$ & $\begin{array}{c}\text { Std. Error of the } \\
\text { Estimate }\end{array}$ \\
\hline 1 & $.978^{\mathrm{a}}$ & .956 & .951 & .343 \\
\hline
\end{tabular}

a. Predictors: (Constant), Professionbalism, Crowdness, Number_of_ATM booths, Customers importance, Formalities_and_rules, ATM, Promtional_Advertisement, One_stop_banking_service, Employees_Behavior, Time consuming

Source: Field survey, 2021

\begin{tabular}{|c|c|c|c|c|c|c|}
\hline \multicolumn{7}{|c|}{ Coefficients $^{\mathrm{a}}$} \\
\hline \multirow{2}{*}{\multicolumn{2}{|c|}{ Model }} & \multicolumn{2}{|c|}{$\begin{array}{c}\text { Unstandardized } \\
\text { Coefficients }\end{array}$} & \multirow{2}{*}{$\begin{array}{c}\text { Standardized } \\
\text { Coefficients } \\
\text { Beta } \\
\end{array}$} & \multirow[t]{2}{*}{$\mathrm{t}$} & \multirow[t]{2}{*}{ Sig. } \\
\hline & & $\mathrm{B}$ & Std. Error & & & \\
\hline \multirow[t]{11}{*}{1} & (Constant) & -.218 & .152 & & -1.430 & .156 \\
\hline & Employees_Behavior (EB) & .081 & .139 & .076 & .583 & .561 \\
\hline & ATM service (ATM S) & -.014 & .133 & -.013 & -.109 & .913 \\
\hline & NUMBER_of_ATM_booths (ATM B) & .041 & .093 & .029 & .436 & .664 \\
\hline & One_stop_banking_service (OSBS) & .444 & .121 & .447 & 3.663 & .000 \\
\hline & Promtional_Advertisement (PA) & -.496 & .164 & -.383 & -3.016 & .003 \\
\hline & Formalities_and_rules ( FR) & -.151 & .099 & -.131 & -1.533 & .129 \\
\hline & Customers_importance (CI) & .843 & .088 & .764 & 9.569 & .000 \\
\hline & Time_consuming (TC) & .550 & .179 & .442 & 3.073 & .003 \\
\hline & Crowded (C) & .130 & .164 & .105 & .789 & .432 \\
\hline & Professionalism $(\mathrm{P})$ & -.340 & .167 & -.326 & -2.033 & .045 \\
\hline \multicolumn{3}{|c|}{ a. Dependent Variable: Banking_positioning } & & & & \\
\hline
\end{tabular}

Source: Field survey,2021

From the above result the regression equation is written as

Banking Positioning $=0.15+0.14 \mathrm{~EB}+0.13$ ATM S +0.09 ATM B +0.12 OSBS $+0.16 \mathrm{PA}+0.10 \mathrm{FR}+0.09$ $\mathrm{CI}+0.18 \mathrm{TC}+0.16 \mathrm{C}+0.17 \mathrm{P}$.

Here, EB, ATM S, ATM B, OSBS, PA, FR, CI, TC, C, and P indicate the Employee Behavior, ATM Service, Number of ATM Booths, One-Stop Banking Service, Promotional Advertisement, Formalities and Rules, Customers Importance, Time Consuming, Crowded, and Professionalism respectively.

Regression enables us to understand how well and crystal relation is maintained through our model. It also helps us to assess whether the cause and effects are acting in which direction and how much the degree of effectiveness work. If the effects of other variables are constant then for each unit increase of employee behavior then banks positioning increases by 0.14 units, for each unit increase of ATM service banks positioning will increase 0.13 units. Similarly for increasing each unit of the number of ATM booths, one-stop banking service, promotional advertisement, formalities, and rules, customer importance banks positioning will increase by 0.09 units, 0.12 units, 0.16 units, and 0.10 units respectively. Besides banks positioning will increase by 0.89 units for increasing each unit of customer importance. For increasing each unit of crowded and professionalism bank positioning will increase by 0.16 units and 0.17 units respectively.

$\mathrm{R}$ square value (also called the coefficient of determination) is the proportion of variance in the dependent variable that can be explained by the independent variables. Our value is 0.978 which means our independent 
variables explain $97.8 \%$ of the variability of our dependent variable. The adjusted $\mathrm{R}$ square value indicates the explanatory power of the independent variables which is 0.951 for bank positioning. It indicates that $95.1 \%$ in the independent variables.

\subsection{Findings}

$>$ From the research study, the researcher has found that customers are not fully satisfied with the behaviors of the government commercials banks. They want more professional and polite behavior from the official staff who contact with customers.

$>$ Most of the customers believe that they did not get open ATM booths 24/7. That's why they are not satisfied with the ATM services of the government commercial banks. They want full services of ATM booths 24 hours 7 days. They think if they don't get ATM services in an emergency so why they will continue with a government commercial bank.

$>$ Around $80 \%$ of respondents believe that government commercial banks' ATM booths are not sufficient enough. For example, whereas DBBL has 4774 ATM booths, IBBL has 1131 ATM booths, BRAC bank has 347 ATM booths, and Trust bank has 235 ATM booths. On the other hand Sonali bank ltd. the largest Commercial bank of Bangladesh has 127 ATM booths of its own. Janata bank has 72 ATM booths, Rupali bank ltd has 35 ATM booths, and Agrani Bank ltd has only 30 ATM booths. Although all of these banks have VISA cards through which customers can withdraw their money from any ATM booths that allow VISA cards but customers want their banks' ATM booths because other banks' ATM booths cut 11.50 taka per transaction.

$>$ Customers want one-stop services from government commercial banks. They have to move one table to another table for getting any services that waste their valuable time. Maximum customers want a onestop service that will save their time.

$>$ Customers claim that they do not get a promotional message from any government bank about their services. Private commercials banks such as IFIC bank ltd, DBBL, Eastern bank ltd, BRAC bank ltd. continuously provide promotional advertisements regarding their service and offerings to attract customers. But government commercial banks' promotional advertisements are not available on TV or other media that's why they have lack of knowledge regarding their services and offerings.

$>$ Most of the customers said that they have to follow many rules regulations and formalities when they go for an account open whether it is a savings account, current account or any kind of deposit account. They claim that the account opening system is complex in government commercial banks. They also claim that loan getting procedure is also very much complex and time-consuming.

$>$ Customers think they will get priority whenever they go to the bank for getting services. But a large portion of the respondents believes that they do not get importance from the employees of the government bank employees. They complain that employees do not talk politely with them.

$>$ The most common complaint regarding commercial banks' service is that getting services from commercial banks is very much time-consuming. They claim that procedures are very much complex and lengthy in government commercial banks. For example, the account opening form of government commercial banks are consists of 7-8 pages. They also claim that if they want to get any loan it takes a minimum of 1 week and sometimes it may take 1 month.

$>$ From this research study, the researcher has found that maximum customers believe that government banks are very much crowded and noisy. They want a calm environment inside the bank.

$>$ Most of the respondents believe that employees are not so much professionals in government commercial banks. Not professionals mean they are not caring about the customers and their wants. They don't want to give time to their customers and listen to what their customers want to say.

\subsection{Recommendations}

$>$ Management of the government commercial banks have to arrange some training and development programs for developing employees' behavior with the customers because banking sectors become very competitive that's why all of the employees should try to retain existing customers and attract new customers for their own sake.

$>$ Like private commercial banks government commercials banks must focus on 24/7 hours ATM service so that customers can withdraw their necessary amount in an emergency. If any technical problem arises then it must be solved within few hours.

$>$ Government commercial banks must have to increase their number of ATM booths. ATM booths must be available in every place especially in every upazilla. Customers said that they have to withdraw money from other banks' ATMs that debit their accounts for transaction fees. If ATM booths are available then they can withdraw money from their ATM booths that will save their transaction fees.

$>$ Government commercial banks have to introduce a one-stop service for satisfying their target customers 
because customers want to save their time by getting quick service.

$>$ Government commercial banks have to provide more promotional advertisements about their products and services to attract new customers and retain existing customers. Although government commercial banks provide so many services to their customers but customers know only a little information regarding their offerings for the absence of promotional advertisement.

$>$ Government commercial banks should bring some changes in their forms. They should use a simple one-page or maximum 2-page form for the savings account, current account, and deposit account. They should provide managerial power to sanction any loan of a minimum of 10 lakhs that will minimize the time schedule for getting any loan.

$>$ Employees must have to listen to their customers carefully and give services accurately and talk with their customers politely.

$>$ Government commercial banks should design different types of account opening forms that consist of only 1 page or a maximum of 2 pages. After getting all the documents from the loan party, the loan must be sanction within the shortest possible time.

$>$ Government banks should recruit more people for serving effectively and efficiently their customers because their number of employees is very less than their number of customers. If employees number increase than customers have to wait less time for getting service they will keep themselves calm and quiet.

$>$ Employees have to be much more professional in their job. They have to keep in mind that all customers are not the same. Different customers have different needs but employees have to handle all the customers technically.

\subsection{Research limitations}

At the time of conducting the research study the researcher faced some limitations that are given in the following:

$>$ The researcher has lack of experience in conducting research

$>$ Time limitation

$>$ Word limitation

$>$ Data accuracy

$>$ Respondents' unwillingness to provide data

\section{Conclusion}

In this survey, the researcher tries to find out the impact of customer perception on commercial banks' positioning. Nowadays it is seen that young generation customers are attracted to private commercial banks as these still have the most customer-oriented services. Old generations of our country are still have faith on government commercial banks but they will also switch to private commercial banks if government commercial banks will not change their service strategies and employee behavior toward customers. In our country, private commercial banks are focused on profit only, but government commercial banks focused both on customer services and profits. Besides profits government commercial banks have a responsibility to serve the people of Bangladesh. That's why they provide some extra services over private commercial banks like Old age allowances, Widows, divorcees an destitute women allowances, Freedom Fighters' allowances, Rehabilitation allowances for acid survival women, Maternal allowances for poor women, Gas bills, Electricity bills, Telephone bills, Water/Sewerage bills, Municipal holding Tax, Passport fees, visa fees, and Travel tax, Customs \& Excise duties, Source tax and VAT, allowances, etc. Government commercial banks always have a lack of employees that is the employees can't handle a large number of customers. So huge amount of workload impact their mentality and behavior. On the other hand, private commercial banks have available employees so that they can easily handle their customers. Their workload is very less than government commercial banks. So they can handle their customers with a smiling face. So government commercial banks have to recruit a sufficient number of employees for serving their customers effectively and efficiently. Government commercial banks have to arrange training and development programs for their employees regarding employee behavior so that government commercial banks occupy a strong positioning on customer minds.

\section{References}

1. Annual Reports of commercial banks

2. Banking Theory Law and Practice - Gordon and Natarajan

3. Devlin, J. and Ennew, C. (1997), "Understanding competitive advantage in retail financial services", International Journal of Bank Marketing, Vol. 15 No. 3, pp. 73-82.

4. Knox, S. (2004), "Positioning and branding your organization", Journal of Product \& Brand Management, Vol. 13 No. 2, pp. 105-15.

5. Kotler P (1984). Marketing Management: Analysis, Planning and Control. Prentice-Hall, Englewood Cliffs, 
NJ.

6. Mukherjee, A. and P. Nath,(2003) "A Model of Trust in Online Relationship Banking," The International Journal of Bank Marketing, Vol. 21, No. 1:5-15, 2003.

7. Naresh K.. Malhotra(2008)- Marketing Research: An Applied Orientation. (5th Ed.).New Delhi: PrenticeHall of India.

8. Strategic positioning and quality determinants in banking service Hatice Camgo“ $\mathrm{z}$ Akdag Management Department, Kadir Has University, Istanbul, Turkey, and Mosad Zineldin School of Business and Economics, Linnaeus University, Va“ xjo“, Sweden

9. Ta, H.P. and Har, K.Y. (2000), "A study of bank selection decisions in Singapore using the Analytical Hierarchy Process", International Journal of Bank Marketing, Vol. 18 No. 4, pp. 170-80.

10. Zineldin, M. (1995), "Bank-company interaction, and relationships: some empirical evidence", International Journal of Bank Marketing, Vol. 13 No. 2, pp. 30-40.

11. Zineldin, M. (1996), "Bank strategic positioning and some determinants of bank selection", International Journal of Bank Marketing, Vol. 14 No. 6, pp. 12-22.

12. Zineldin, M. (2002), "Managing in the @ age: banking service quality and strategic positioning”, Measuring Business Excellence, Vol. 6 No. 4, pp. 38-43.

13. https://www.bb.org.bd/en/index.php

14. https://www.jb.com.bd/

15. https://www.rupalibank.org/

16. https://www.sonalibank.com.bd/

17. https://www.agranibank.org/

\section{Biographics}

Asifa Nargis ${ }^{1}$ (Corresponding author), Khagrachari, 15 May, 1992.

B.B.A (management) 2014, University of Chittagong, Chittagong, Bangladesh.

M.B.A (human resource management) 2015, University of Chittagong, Chittagong, Bangladesh.

Gourab Chakma ${ }^{2}$, Rangamati, 9 October, 1992.

B.B.A (management) 2014, University of Dhaka, Dhaka, Bangladesh.

M.B.A (human resource management) 2015, University of Dhaka, Dhaka, Bangladesh.

Kamrul Hossain ${ }^{3}$,Khagrachari, 6 November, 1992.

B.B.A (marketing) 2015, Comilla University, Comilla, Bangladesh.

M.B.A (marketing) 2016, Comilla University, Comilla, Bangladesh. 